\title{
Evaluation of the Bioactive Compounds in Leaves and Stem-Bark of Piptadeniastrum africanum (Hook.f.) Brenan (Family Fabaceae)
}

\author{
Felix Okponanabofa Youkparigha ${ }^{* 1}$, Bio Louis Nyananyo ${ }^{2}$ Ayodele Adelusi Oyedeji ${ }^{1}$ \\ ${ }^{1}$ Department of Biological Sciences, Faculty of Science, Niger Delta University, Wilberforce Island, Bayelsa \\ State, Nigeria \\ ${ }^{2}$ Department of Plant Science and Biotechnology, Faculty of Science, University of Port Harcourt, Port \\ Harcourt, Rivers State, Nigeria
}

${ }^{*}$ Corresponding Author: Felix Okponanabofa Youkparigha, Department of Biological Sciences, Faculty of Science, Niger Delta University, Wilberforce Island, Bayelsa State, Nigeria

\begin{abstract}
This study evaluated the bioactive compounds in leaves and stem-bark extracts of Piptadeniastrum africanum (Hook.f.) Brenan. Specimens of the plant were obtained from the tropical rain forest in several communities in the eight local government areas of Bayelsa State, Nigeria. The samples were extracted using water, and the bioactive constituents were analyzed using qualitative and quantitative techniques. The quantitative results revealed that Alkaloids, Saponins, Flavonoids, Glycosides, Phytate, Tannins, Oxalate and Phenols concentrations were $5.08 \%, 17.60 \%, 5.72 \%, 0.90 \mathrm{mg} / \mathrm{kg}, 0.0917 \%, 2.684 \%, 36.55 \mathrm{mg} / \mathrm{g}$ and $376.08 \mathrm{mg} / \mathrm{kg}$, respectively in the leaves and 3.00\%, 13.60\%, 7.34\%, 0.50mg/kg, 0.0917\%, 2.732\%, 61.02 $\mathrm{mg} / \mathrm{g}$ and $376.08 \mathrm{mg} / \mathrm{kg}$, respectively in the stem-bark. The qualitative results showed that saponins, and terpenes were very high and tannins, steroids, phenol and flavonoids were fairly present in the leaves of $P$. africanum. While in the stem bark saponins was very high, phenol was high, and tannins, terpenes, steroids and flavonoids were fairly present. The concentrations of the bioactive ingredients varied based on plant parts for some bioactive compounds. Both the qualitative analysis and quantitative determination of the metabolites showed that the plant under study is rich in phytochemicals. Therefore, there is need for further research to focus on other medicinal properties of the plant parts.
\end{abstract}

Keywords: Medicinal plant, Metabolites, Phytochemicals, Traditional medicine

\section{INTRODUCTION}

Piptadeniastrum africanum is a forest tree that belongs to the family Fabaceae, Subfamily Mimosoideae (Airy Shaw, 1985). The plant can grow up to $45-50 \mathrm{~m}$ high and 3-5 $\mathrm{m}$ in girth with conspicuous plank-like buttresses, straight bole, with fine fern-like foliage. The plant has compound leaves with the basal pinnae low down on the common stalk which is usually $10-12 \mathrm{~cm}$ and grooved on the adaxial surface. The plant bears fruits which are usually $15-35 \mathrm{~cm}$ long and $15-35 \mathrm{~mm}$ wide. The fruits have seeds which are about 20-25 mm attached to the margin of the pod by a slender thread running from the middle and each is provided with wings that are papery, dark brown, and elongated. These wings are about 4-8 cm long and 10-25 mm wide (Hutchinson and Dalziel, 1958; Nyananyo, 2006).

Piptadeniastrum africanum (Hook.f.) Brenan is endemic to tropical Africa. It is found in Angola, Central African Republic, Gabon, Ghana, Ivory Coast, Liberia, Nigeria, Sierra Leone, Sudan, Togo, Uganda, Zaire, Congo, Equatorial Guinea (Brenan, 1955; Richard, 2013). The plant is found in the Niger Delta region of Nigeria especially on river banks in the riverine areas of the rain forest (Nyananyo, 2006). The plant is a valuable tree that is used as timber and for construction works.

Like many medicinal plants, $P$. africanum is used by traditional medicine practitioners for the treatment of several disease conditions especially in the region where the plant is endemic. Scientific validations have been made with regards to the medicinal potentials of the plant about some specific diseases. The plant parts such as the leaves, stem and root are used by traditional medicine practitioners. Authors have reported that medicinal plants are plants in which one or more parts 
(leaves, root, stem, flower, fruit, seed) have therapeutic properties (Kigigha et al., 2015; Epidi et al., 2018; Izah and Aseibai, 2018; Izah et al., 2018a -e; Kigigha et al., 2018a,b).

Specifically, Ateufack et al. (2015) reported that aqueous and methanol extracts of the stem bark of $P$. africanum could stimulate essential cellular mechanisms (such as migration and proliferation of epithelial cells that may have cytoprotective activity by stimulating the release of prostaglandins that have gastroprotective and ulcer healing effects). Line-Edwige et al. (2009) reported that alcoholic extracts of the roots of $P$. africanum have antiproliferative activity on human colon cancer cell line. Other authors have indicated that the plant has analgesic, anti-inflammatory, and anti- gastric ulcer activity (Jiofack, 2008; Diffoum, 2012; Ateufack et al., 2015). Neuwinger (2000), Jiofack et al. (2008) and Owoeye et al. (2018), reported that the bark of the plant is used to prepare decoctions for the treatment of cough, bronchitis, headache, mental disorders, stomach-ache, dysmenorrhea and male impotence (internal) and treatment of fever, toothache, pneumonia, oedema, skin complaints and even leprosy (external). The authors further reported that the leaves can be used for the treatment of gonorrhea and abdominal pains. Owoeye et al. (2018) reported that the root can be used as abortifacient, aphrodisiac and for the treatment of mental disorder.

Studies have suggested that plants are able to confer therapeutic properties because of the bioactive compounds they contain (Kigigha et al., 2015; Epidi et al., 2018; Izah and Aseibai, 2018; Izah et al., 2018a -e; Kigigha et al., 2018a,b). To this effect, a previous study by Owoeye et al. (2018) assessed the phytochemical properties of the bark of the plant. This present study is aimed at assessing the phytochemical and anti-nutritional compounds in leaves and stem-bark of $P$. africanum.

\section{Materials ANd Methods}

\subsection{Plant Collection and Identification}

The leaves and stem of $P$. africanum were collected from several communities in the eight local government area of Bayelsa State, Nigeria. The plant specimens were identified at the Forest Herbarium Ibadan of the Forestry Research Institute of Nigeria (FRIN) and the Herbarium of the Department of Plant Science and Biotechnology, University of Port Harcourt, Rivers State. Voucher Specimens of the plant were deposited in these herbaria for reference and further studies.

\subsection{Phytochemical Analysis}

Phytochemical analysis included both the screening of plant samples for the presence of phytochemicals (qualitative analysis) and the determination of the specific amounts of the various phytochemicals present in the plant samples (quantitative analysis) using standard procedures by Lambert and Muir (1973), Stewarte et al. (1974), Sofowora (1993), Edeoga et al. (2005), Okwu (2005), Doherty et al. (2010), Kanife et al. (2012)

Specifically, the quantitative determination of the bioactive compounds was carried out according to methods previously established in literature viz: alkaloids (Harborne, 1973), flavonoids (Boham and Kocipal-Abyazan, 1994), Phenol (King and Armstrong, 1934), phytic acid (Kent-Jones and Amos, 1967), Tannic acid (AOAC, 1970). Saponins determination was carried out by Soxhlet extraction/Gravimetric method (Harborne, 1973), cyanogenic glycoside by Alkaline Titration Method (AOAC, 1984) and oxalate by standardization of potassium permanganate solution by sodium oxalate (Lambert and Muir, 1973).

\section{RESULTS AND DISCUSSION}

Table 1 presents results of the qualitative analysis of crude phytochemical constituents of $P$. africanum. The result showed that saponins and terpenes were very high while tannins, steroids, phenol and flavonoids were fairly present in the leaf of $P$. africanum. In the stem bark, saponins is very high; phenol is high, while tannins, terpenes, steroids and flavonoids are fairly present.

The quantitative crude bioactive compounds present in $P$. africanum are presented in Table 2. The amounts of Alkaloids, Saponins, Flavonoids, Glycosides, Phytate, Tannins, Oxalate and Phenols are $5.08 \%, 17.60 \%, 5.72 \%, 0.90 \mathrm{mg} / \mathrm{kg}, 0.0917 \%, 2.684 \%, 36.55 \mathrm{mg} / \mathrm{g}$ and $376.08 \mathrm{mg} / \mathrm{kg}$, respectively in the leaf and $3.00 \%, 13.60 \%, 7.34 \%, 0.50 \mathrm{mg} / \mathrm{kg}, 0.0917 \%, 2.732 \%, 61.02 \mathrm{mg} / \mathrm{g}$ and $376.08 \mathrm{mg} / \mathrm{kg}$, respectively in the stem-bark. The study showed that alkaloids, saponins, glycosides were apparently 
Evaluation of the Bioactive Compounds in Leaves and Stem-Bark of Piptadeniastrum africanum (Hook.f.) Brenan (Family Fabaceae)

higher in the leaf compared to the stem-bark. Phenols and phytate concentrations were same in both plant parts. While flavonoids, tannins, oxalate were apparently higher in the stem-bark when compared to the leaf. Both the qualitative analysis and quantitative determination of metabolites showed that the plant under study is rich in phytochemicals.

The phytochemicals of $P$. africanum appeared to be the aspect of the plant that has been most studied. This is possibly so because plants have been shown to contain secondary metabolites that can also protect humans against diseases (Doughari et al., 2009). To these effects most of the phytochemicals have been reported by several authors for specific functions. For instance, Agu and Thomas (2012) reported that alkaloids have defense mechanisms through which plants ward off pests. This suggests the medicinal properties (such as analgesic, antispasmodic and bactericidal effects) of alkaloids from plants (Kigigha et al., 2015; Epidi et al., 2016a, b; Doherty et al., 2010; Osuntokun and Oluwafoise, 2015). Alkaloids are also essential for the treatment of ulcer (Ateufack et al., 2015). The values of alkaloids observed in this study are lower than the values reported by Owoeye et al. (2018).

Saponins in the leaf and stem-bark is an indication that the plant could be used as expectorant, cough suppressant and it also has hemolytic activity (Sofowora, 1993; Kigigha et al., 2015; Okwu, 2005; Osuntokun and Oluwafoise, 2015; Epidi et al., 2016a,b). Bark decoctions of P. africanum are useful in the treatment of cough, bronchitis, and genito-urinary infections (Jiofack, 2008; Fern, 2014). Brusotti et al. (2013) reported that the saponin fraction of the methanolic extract of the stem bark of $P$. africanum has been demonstrated to be a good candidate for the control of a pathogen of rice blast disease, Pyricularia grisea. These may be linked to the biological activities of saponins contained in the extracts of these plants. The values were high and are comparable to values reported by Owoeye et al. (2018).

Table1. Results of qualitative analysis of crude phytochemical constituents of P. africanum

\begin{tabular}{|l|l|l|}
\hline Phytochemical & Leaf of P. africanum & Bark of P. africanum \\
\hline Saponins & +++ & +++ \\
\hline Tannins & + & + \\
\hline Terpenes & +++ & + \\
\hline Steroids & + & + \\
\hline Phenols & + & ++ \\
\hline Flavonoids & + & + \\
\hline
\end{tabular}

$$
\begin{aligned}
& \text { KEY } \\
& +++=\text { very highly present } \\
& ++=\text { highly present }
\end{aligned}
$$

Table2. Quantities of crude phytochemicals present in plants studied

\begin{tabular}{|l|l|l|}
\hline Phytochemicals & Leaf of $P$. africanum & Bark of P. africanum \\
\hline Alkaloids (\%) & 5.08 & 3.00 \\
\hline Saponins (\%) & 17.60 & 13.60 \\
\hline Flavonoids (\%) & 5.72 & 7.34 \\
\hline Glycosides (mg/kg) & 0.900 & 0.50 \\
\hline Phytate (\%) & 0.0917 & 0.0917 \\
\hline Tannins (\%) & 2.684 & 2.732 \\
\hline Oxalate $(\mathrm{mg} / \mathrm{g})$ & 36.55 & 61.02 \\
\hline Phenols $(\mathrm{mg} / \mathrm{kg})$ & 376.08 & 376.08 \\
\hline
\end{tabular}

Flavonoids have been reported to have antioxidant, anticarcinogenic, antimicrobial and antitumor properties (Kigigha et al., 2015; Osuntokun and Oluwafoise, 2015). Flavonoids are also essential for the treatment of ulcer (Ateufack et al., 2015). As such the values obtained from this study suggest the biological activity of flavonoids. Glycosides are known for several biological activities including analgesic, antipyretic, and anti-inflammatory effects. Some types of glycosides such as the cyanogenic is found in several plants and they aid to defend the plant against herbivores and pathogens due to their bitterness and release of poisonous hydrogen cyanide once the plant tissue is wounded (Zagrobelny et al. 2004). 
Tannins are known to occur abundantly in the bark of trees where they act as a barrier to microorganisms. Tannin is astringent in nature and has the ability to bind or precipitate proteins and various other organic compounds making them unavailable for absorption. Plants rich in Tannin are said to have several medical applications (Okuda, 2005; Doughari et al, 2009). Tannins have health importance such as wound healing, varicose ulcers, hemorrhoids, frostbite and burns, and it has the ability to regenerate skin, as well as anti-inflammatory and anti-diuretics activity (Okwu and Okwu, 2004; Doherty et al., 2010; Kigigha et al., 2015; Osuntokun and Oluwafoise, 2015).

In this study steroids and terpenes were detected through qualitative approach. Okeke et al. (2015) suggested that the occurrence of steroids in plants could be helpful in the classification of closely related species. Furthermore, plant steroids are known to possess medicinal, pharmaceutical and agrochemical activities (Patel and Savjani, 2015). Plant steroids are classified into phytosterols and brassinosteroids. Authors have reported that phytosterols lower plasma cholesterol by preventing the absorption of cholesterol and cancer prevention potentials (Ogbe et al., 2015; Sultan and Raza, 2015). Brassinosteroids also help plants resist biotic and abiotic stress by protecting plants from the toxicity of herbicides, fungicides and insecticides (Xia et al, 2009).

The results of qualitative screening of phytochemicals in this study is contrary to that reported by Owoeye et al (2018) in which both steroids and terpenoids were not detected in the stem bark of $P$. africanum. In this study, both compounds were present. The variations could be as a result of differences in the environment of the plants, the manner of collection of the plant samples, the process of extraction or the status of the chemicals used for the extraction of the phytochemicals from the samples.

Phytate is a phosphorylated form of Inositol and its major storage of phosphorus in all leafy vegetables (Harland and Oberleas, 1987; Horner, et al., 2005; Habtamu and Negussie, 2018). Phytic acid is found in plant tissues as salts of cations such as potassium, magnesium and calcium (Natesh et al., 2017) and has both beneficial and detrimental effects on human. Therefore, the presence of phytate in plants used for medicinal purpose is worth considering as a result of the well-known antinutritional activities of phytic acid. Phytic acid has the tendency to reduce the bioavailability of essential metals such as zinc and iron, and binds with proteins and negatively affects the action of digestive enzymes (Aberoumand, 2012; Natesh et al., 2017). However, phytic acid can also inhibit the formation of calcium oxalate and calcium phosphate crystals that could cause kidney stone disease. Oxalates have been reported in flowering plants (Natesh, 2017). In humans, oxalates could be harmful. The ingestion of high levels of oxalate through herbal medicine could cause hyperoxaluria (Horner et al., 2005; Radek and Savage, 2008). Phenolic compounds are among the most abundant secondary metabolites in plants. Some phenolic compounds have powerful antioxidant properties and they aid to prevent oxidative stress that could cause degenerative diseases conditions such as cancer (Dai and Mumper, 2010).

\section{CONCLUSION}

This study investigated the phytochemical and anti-nutritional compounds in leaf and stem-bark of $P$. africanum. The result revealed varying concentrations of Alkaloids, Saponins, Flavonoids, Glycosides, Phytate, Tannins, Oxalate and Phenols through quantitative approach and saponins, terpenes, tannins, steroids, phenol and flavonoids through qualitative approach. The presence of phytochemicals like tannins, phytate and oxalate suggest the possible adverse effects of the continuous use of herbal preparations from leaf and stem bark of this plant on human health. However, the rich presence of other phytochemicals in this plant suggests its vast pharmacological potentials. Therefore, there is need for further research to be carried out on the anti-nutritional characteristics to reveal the concentrations that could be toxic to human health as well as other medicinal properties of the plant that have not been documented.

\section{ACKNOWLEDGEMENT}

This paper is based on part of post graduate project work of F.O. Youkparigha supervised by Prof. B.L. Nyananyo at the Niger Delta University, Wilberforce Island, Nigeria. 


\section{REFERENCES}

[1] Aberoumand, A. (2012). Screening of Phytochemical Compounds and Toxic Proteinaceous Protease Inhibitor in Some Lesser-Known Food Based Plants and Their Effects and Potential Applications in Food. International Journal of Food Science and Nutrition Engineering, 2(2), 1-5

[2] Airy Shaw, H.K. (1985). J.C. Willis: A dictionary of flowering plants and ferns 8th edition. Airy Shaw, H.K. (Revised)

[3] Agu, G.C., \& Thomas, B.T. (2012). Antibacterial Activities of Ethanol and Aqueous Extracts of Five Nigerian Medicinal Plants on Some Wound Pathogens. Nature and Science, 10(2),78-84.

[4] AOAC (1970). Official Methods of Analysis of the Association of official Analytical Chemists. Horwitz, W. (Ed). 11th edition. Pp 240-241. Washington, DC.

[5] AOAC (1984). Official Methods of Analysis. Association of Official Analytical Chemists. 14th Edition, AOAC, Arlington.

[6] Ateufack, G., Mokam E.C.M., Mbiantcha, M., Feudjio, R.B.D., David, N. \& Kamanyi, A. (2015). Gastroprotective and ulcer healing effects of Piptadeniastrumafricanumon experimentally induced gastric ulcers in rats. BMC Complement Altern Med. 15, 214. Doi: 10.1186/s12906-015-0713-5.

[7] Boham, B.A. \& Kocipal-Abyazan, R. (1994). Flavonoids and condensed tannins from leaves of Vaccinium vaticulatum and V. calycinium. Pacific Science, 48, 458-463

[8] Brenan, J.P.M. (1955). Piptadeniastrum africanum. Kew Bulletin, 179

[9] Brusotti, G., Tosi, S., Tava, A., \& Caccialanza, G. (2013). Antimicrobial and phytochemical properties of stem bark extracts from Piptadeniastrum africanum (Hook.f.) Brenan. Industrial Crops and Products, 43 (1), 612-616

[10] Dai, J. \& Mumper, R.J. (2010). Plant Phenolics: Extraction, Analysis and Their Antioxidant and Anticancer Properties. Molecules, 15, 7313-7352; Doi: 10.3390/molecules15107313

[11] Diffoum J.B. (2012). Propriétés analgésiques et anti-inflammatoires de l'extrait aqueux des écorces de Piptadeniastrum africanum (Mimosaceae) chez le rat. LAPHYPHA, UDs: Thèse de MASTER; p. 94.

[12] Doherty, V.F., Olaniran, O.O.,\& Kanife, U.C. (2010). Antimicrobial activities of Aframomum melegueta(Alligator pepper). International Journal of Biology, 2(2), $126-131$.

[13] Doughari, J.H., Human, I.S., Bennade, S. \& Ndakidemi, P.A. (2009). Phytochemicals as chemotherapeutic agents and antioxidants: Possible solution to the control of antibiotic resistant verocytotoxin producing bacteria. Journal of Medicinal Plants Research, 3(11),839-849.

[14] Edeoga, H.O., Okwu, D.E., \&Mbaeble, B.O. (2005). Phytochemical constituents of some Nigerian medicinal plants. African Journal of Biotechnology, 4, $685-688$.

[15] Epidi, J.O., Izah, S.C., \& Ohimain, E.I. (2016). Antibacterial and synergistic efficacy of extracts of Alstonia boonei tissues. British Journal of Applied Science, 1(1), 21 - 26.

[16] Epidi, J.O., Izah, S.C., Ohimain, E.I., \& Epidi, T.T. (2016). Antibacterial and synergistic potency of tissues of Vitex grandifolia. Biotechnological Research, 2(2), 69-76.

[17] Fern, K. (2014). Piptadeniastrum africanum. Useful tropical Plants Database Retrieved from: https://www. Tropical.thefern.infoviewtropical.php?id = Piptadeniastrum+africanum. Accessed [17-07-2016].

[18] Habtamu, F.G. \& Negussie, R. (2018). Anti-dietary factors in plant foods:potential effects: Advanced Research Journal of Microbiology, 5(2),100-113

[19] Harborne, J.B. (1973). Phytochemical methods- A Guide to modern Techniques of plant analysis. Chapman and Hall, London. 278pp.

[20] Harland, B.F. \& Oberleas, D. (1987). Phytate in foods. Energy. Nutrition women, Karger Publishers, Japan. Pp. 235-259.

[21] Horner, H. T., Cervantes-Martinez, T., Healy, R., Reddy, M.B., Deardorff, B.L.,Bailey, T.B.,\& Palmer, R.G. (2005). Oxalate and Phytate Concentrations in Seeds of Soybean Cultivars [Glycine max (L.) Merr.]. Journal of Agricultural and food chemistry, 53, 7870-7877

[22] Hutchinson, J. and Dalziel, J.M. (1958). Flora of West Tropical Africa. 2nd edition Vol. 1, Part 2. Revised by Keay, R.W.J. Crown Agents for Oversea Governments and Administrations, MillBank, London. 532pp.

[23] Izah, S.C. (2018). Some determinant factors of antimicrobial susceptibility pattern of plant extracts. Research and Review Insight, 2(3), 1-4

[24] Izah, S.C., \& Aseibai, E.R. (2018). Antibacterial and Synergistic activities of methanolic leaf extract of Lemon grass (Cymbopogon citratus) and rhizome of Ginger (Zingiber officinale) against Escherichia coli, Staphylococcus aureus and Bacillus species. ACTA Microbiology, 1(6), 26-30. 
[25] Izah, S.C., Uhunmwangho, E.J., \& Dunga, K.E. (2018a). Studies on the synergistic effectiveness of methanolic extract of leaves and roots of Carica papaya L. (papaya) against some bacteria pathogens. International Journal of Complementary and Alternative Medicine, 11(6), 375-378.

[26] Izah, S.C., Uhunmwangho, E.J., \& Eledo, B.O. (2018b). Medicinal potentials of Buchholzia coriacea (wonderful kola). Medicinal Plant Research, 8(5), 27-43.

[27] Izah, S.C., Uhunmwangho, E.J., \& Etim, N.G. (2018c). Antibacterial and synergistic potency of methanolic leaf extracts of Vernonia amygdalina L. and Ocimum gratissimum L. Journal of Basic Pharmacology and Toxicology, 2(1), 8-12

[28] Izah, S.C., Uhunmwangho, E.J., Dunga, K.E., \& Kigigha, L.T. (2018d). Synergy of methanolic leave and stem-back extract of Anacardium occidentale 1. (cashew) against some enteric and superficial bacteria pathogens. MOJ Toxicology, 4(3), 209-211.

[29] Izah, S.C., Zige, D.V., Alagoa, K.J., Uhunmwangho, E.J., \& Iyamu, A.O. (2018e). Antibacterial Efficacy of Aqueous Extract of Myristica fragrans (Common Nutmeg). EC Pharmacology and Toxicology, 6(4), 291-295.

[30] Jiofack, T.R.B. (2008). Piptadeniastrum africanum (Hook.f.) Brenan. Timbers Boisd'oeuvre. Retrieved from: Https??database.Prota.org/PROTA html/Piptadeniastrum\%20africanum_En.html. Accessed [04-042014]

[31] Kanife, U.C., Odesanmi, O.S., \& Doherty, V.F. (2012). Phytochemical composition and antifungal properties of leaf, stem and florets of Panicummaximum Jacq. (Poaceae). International Journal of Biology, 4(2), 64-69

[32] Kent-Jones, D.W. \& Amos, A.J. (1967). A Modern Cereal Chemistry. 6th Edn., Food Trade Press, London pp 558-563

[33] Kigigha, L.T., Izah, S.C., \& Ehizibue, M. (2015). Activities of Aframomum melegueta Seed Against Escherichia coli, S. aureus and Bacillus species. Point Journal of Botany and Microbiology Research, $1(2), 23-29$.

[34] Kigigha, L.T., Izah, S.C., \& Uhunmwangho, E.J. (2018a). Assessment of hot water and ethanolic leaf extracts of Cymbopogon citratus Stapf (Lemon grass) against selected bacteria pathogens. Annals of Microbiology and Infectious Diseases, 1(3), 1- 5.

[35] Kigigha, L.T., Selekere, R.E., \& Izah, S.C. (2018b). Antibacterial and synergistic efficacy of acetone extracts of Garcinia kola (Bitter kola) and Buchholzia coriacea (Wonderful kola). Journal of Basic Pharmacology and Toxicology, 2(1), 13-17.

[36] King, E.J. \& Armstrong, A.R. (1934). A convenient method for determining serum and bile phosphate activity. Canadian Medical Association Journal, 31,376

[37] Lambert, J. and Muir, T.A. (1973). Practical Chemistry. Heinemann Educational Books, London. 467pp.

[38] Line-Edwige, M., Raymond, F.T.G., François, E., \& Edouard, N.E. (2009). Antiproliferative Effect of Alcoholic Extracts of Some Gabonese Medicinal Plants on Human Colonic Cancer Cells, Afr J Tradit Complement Altern Med., 6(2), 112-117.

[39] Natesh, H.N., Abbey, L. \& Asiedu. S.K. (2017). An overview of nutritional and anti-nutritional factors in green leafy vegetables. Horticulture International Journal 1(2), 58-65.

[40] Neuwinger, H.D. (2000). African Traditional Medicine: A dictionary of plant use and applications. Medpharm Scientific, Stuttgart, Germany, 589 pp.

[41] Nyananyo, B.L. (2006). Plants from the Niger Delta. Onyoma Research publications, Nigeria. 403pp.

[42] Ogbe, R.J., Ochalefu, D.O., Mafulul, S.G., \&Olaniru, O.B. (2015). A review on dietary phytosterols: Their occurrence, metabolism and health benefits.Asian Journal of Plant Science and Research, 5(4), 10-21

[43] Okeke, C.U., Iroka, C.F., Izundu, A.I., Okereke, N.C., \& Nyananyo, B.L. (2015) Taxonomic Implications of Flavonoids and Steroids in the Species of Stachytarpheta present in Awka, Nigeria. The Pharma Innovation Journal, 4(6), 04-06

[44] Okuda, T. (2005). Systematics and health effects of chemically distinct tannins in medicinal plants. Phytochemistry, 66(17), 2012-2031.

[45] Okwu, D.E. (2005). Phytochemicals, Vitamins and Mineral contents of two Nigeria Medicinal Plants. International Journal of Molecular Medicine and Advance Sciences, 1 (4), 375-381

[46] Okwu, D.E. \& Okwu, M.E. (2004). Chemical composition of Spondias mombia Linn plant parts. Journal of Sustain Agricultural Environment, 6, 140-147.

[47] Osuntokun,O.T. \& Oluwafoise, B.O. (2015). Phytochemical screening of ten Nigerian medicinal plants. International Journal of Multidisplinary Research and Development, 2(4), 390-396. 
[48] Owoeye, E.A., Ogboru R.O., Bakpolor V.R. \& Omobude D.E. (2018). Phytochemical screening and proximate analysis of the bark of Piptadeniastrum africanum Hook (Fabaceae). World News of Natural Sciences, 19, 135-141

[49] Patel, S.S. \& Savjani, J.K. (2015). Systematic review of plant steroids as potential anti-inflammatory agents: Current status and future perspectives. The Journal of Phytopharmacology, 4(2), 121-125

[50] Radek, M. \& Savage, G. (2008). Oxalates in some Indian green leafy vegetables. International Journal of Food Sciences and Nutrition, 59(3), 246-260.

[51] Richard, W. (2013). Piptadeniastrum africanum (Hook.f.) Brenan. International Legume Database Information Service. Retrieved from: https://www.ildis.Org/cgi-bin/Araneus-pl. Accessed [23-08-2017]

[52] Sofowora, A. (1993). Medicinal plants and Traditional medicine in Africa. Spectrum Books limited, Ibadan, Nigeria, 346pp.

[53] Stewarte, A.H., Grimshaw, H.M., John, A.P., \& Christopher, Q. (1974): Chemical analysis of ecological materials. Blackwell Scientific Publications, London 565pp.

[54] Sultan, A. \& Raza, A.R. (2015). Steroids: A Diverse Class of Secondary Metabolbites. Medicinal Chemistry, 5, 310-317

[55] Xia, X.J., Zhang, Y., Wu, J.X., Wang, J.T., Zhou, Y.H., Shi, K. ... Yu JQ. (2009).Brassinosteroids promote metabolism of pesticides in cucumber. Journal of Agricultural and Food Chemistry, 57(18), 84068413.

[56] Zagrobelny, M., Bak, S., Rasmussen, A.V., Jorgensen, B., Naumann, C.M.,\& Moller, B.L. (2004). Cyanogenic glucosides and plant insect interactions. Phytochemistry, 65, 293-306

Citation: Felix Okponanabofa Youkparigha, et.al.,(2019). Evaluation of the Bioactive Compounds in Leaves and Stem-Bark of Piptadeniastrum africanum (Hook.f.) Brenan (Family Fabaceae).. International Journal of Medicinal Plants and Natural Products (IJMPNP), 5(2), pp.1-7. http://dx.doi.org/10.20431 /2454-7999.0502001

Copyright: () 2019 Authors, This is an open-access article distributed under the terms of the Creative Commons Attribution License, which permits unrestricted use, distribution, and reproduction in any medium, provided the original author and source are credited. 